\title{
RED CORUNDUM, SAPPHIRINE AND KORNERUPINE FROM KITTILÄ, FINNISH LAPLAND
}

\author{
Ilmari Haapala, JaAk ko Sirvola, Pentti Ojanperä \\ and Veijo Yletyinen
}

\begin{abstract}
Haapala, I., Sirvola, J., Ojanperä, P. and Yletyinen, V.: Red corundum, sapphirine and kornerupine from Kittilä, Finnish Lapland. Bull. Geol. Soc. Finland, 43, 221-231.

Mineral assemblages containing corundum, sapphirine and kornerupine are present in a high-grade metamorphic amphibolite-hornblendite formation near the great granulite complex of Finnish Lapland. A low-grade metamorphism has slightly retrogressed the mineral assemblages and partly destroyed corundum, sapphirine and kornerupine. Chemical analyses and physical properties including single-crystal data are presented for hornblende, gedrite, sapphirine and kornerupine.
\end{abstract}

Ilmari Haapala, Jaakko Siivola, Pentti Ojanperä and Veijo Yletyinen, Geological Survey of Finland, Otaniemi, Finland.

\section{Introduction}

In September, 1965 the Geological Survey of Finland received a small boulder containing red corundum (Fig. 1) from a place called Paaraskalla in the Kittilä wilderness in Finnish Lapland. This sample was found by a school-boy, Mikko Tervo. During short periods in 1966-68 the area was studied for economic corundum deposits, and many tens of boulders and some outcrops containing corundum were found. The corundum occurs in strongly tectonized amphibolitichornblenditic rocks. When studying the Paaraskalla samples in the laboratory, sapphirine and kornerupine were identified. Kornerupine is a mineral new to Finland, and sapphirine has been described from only one locality (Rouhunkoski 1969). Because it was considered that the gravel at Paaraskalla could contain some precious conrundun (ruby), panning was carried out on the spot. A great deal of corundum was obtained by panning the soft rock weathered during preglacial time and now located beneath the normal moraine. Many of the corundum crystals were weakly translucent and of a pink or red colour, but no precious corundum was found. Six crystals were polished by Mr. Tauno Paronen, but no star figures were visible. The amount of corundum in the rock is so small and the crystals so impure that quarrying for industrial corundum would not be economic. Nevetheless, the occurrence is interesting because of its mineralogy, chemistry and metamorphic facies.

The field work for this study was done by Haapala and Yletyinen. The chemical analyses were made by Siivola and Ojanperä, while Haapala is responsible for other mineralog:cal and petrological studies and the conclusions. 


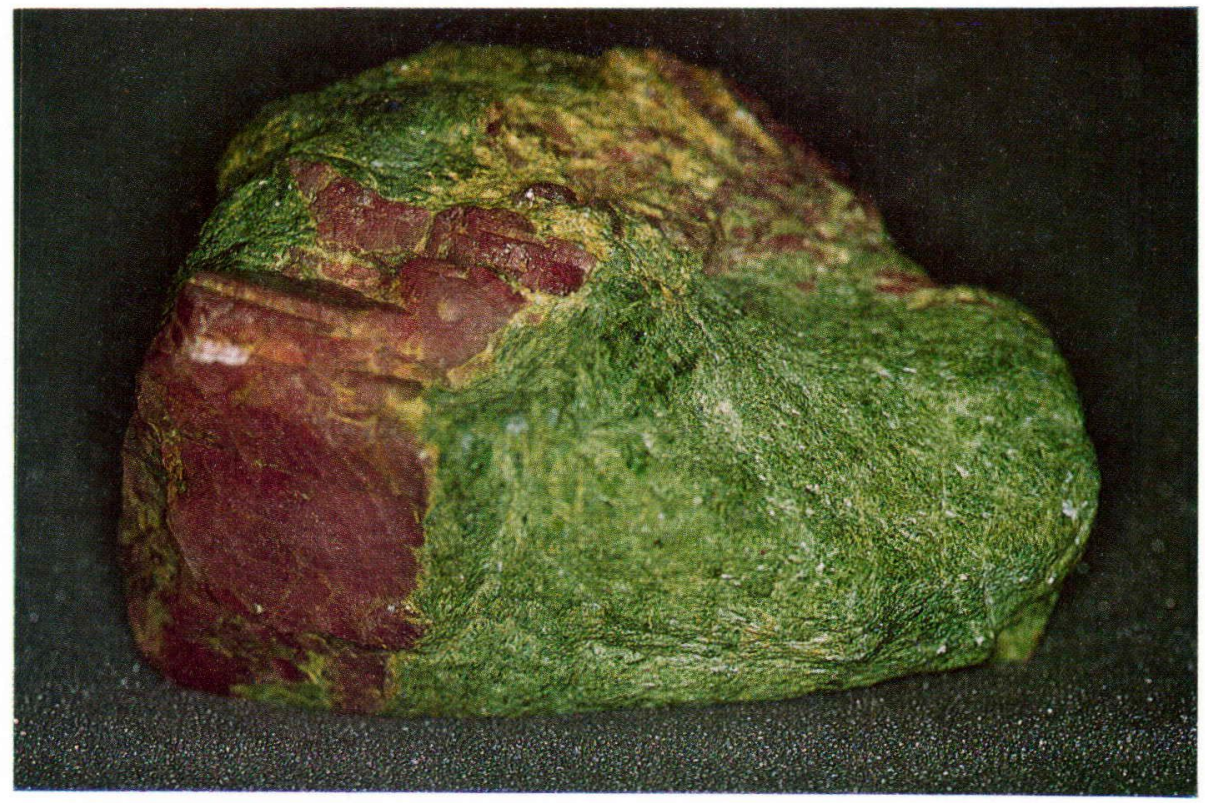

Fig. 1. The boulder sample containing red corundum and kornerupine from Paaraskalla, Kittilä. Natural size. Photo Erkki Halme.

\section{Geology}

The corundum, sapphirine and kornerupine occur in medium-grained metamorphic maficultramafic rocks with indistinct layered or gneissose structure. The mineral composition of the rocks is variable but in general they are amphibolite or, rarely, hornblendite. The main minerals are hornblende and plagioclase. In places hornblende forms phenocrysts up to several centimeters in diameter. Plagioclase is often concentrated in thin bands parallel to the foliation and to the elongation of the complex. However, plagioclase veinlets cutting the foliation have also been found. Plagioclase of the amphibolitehornblendite formation may be almost fresh anorthite, but often it is strongly altered to sericite, clinozoisite and, in small amounts, to carbonate. The unaltered plagioclase was identified as anorthite by microprobe technique.

On the basis of thin section studies, the following main mineral associations were distinguished in the amphibolite- hornblendite formation:
1. Hornblende-plagioclase \pm chlorite (most common type)

2. Hornblende-plagioclase-corundum \pm chlorite

3. Hornblende-gedrite-sapphirine-corundum (-chlorite-plagioclase)

4. Hornblende-corundum-kornerupine-sericiteclinozoisite-chlorite (only one boulder)

Alteration products of plagioclase, and aluminous chromite are common accessories. The kornerupine-bearing sample also contains some dravite.

Corundum occurs as crystals detectable with the naked eye in only a few outcrops (Nos. 40, 41 and 44 in Fig. 2). Microscopically, small remnants of replaced corundum can be detected in outcrop 3. The corundum crystals often form rows of grains parallel to the foliation of the rock (Fig. 3). Boulders containing corundum can be traced over a long narrow zone parallel to the formation, part of which is visible in Fig. 2. This 


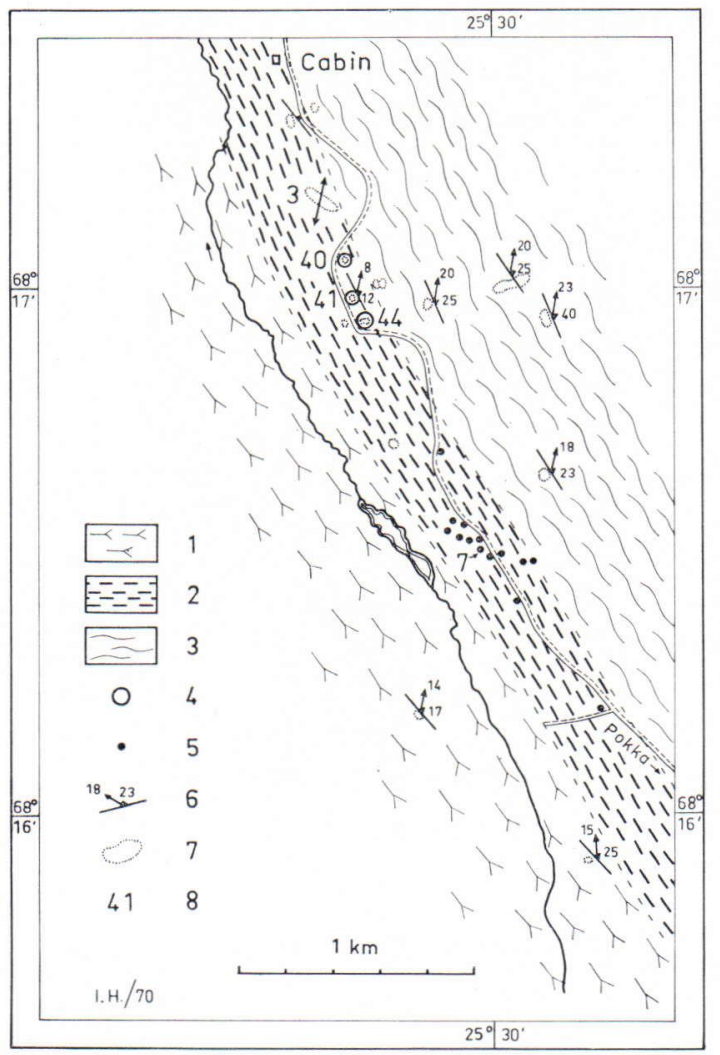

Fig. 2. A map showing the locations of corundumbearing outcrops and boulders. 1. Granite gneiss; 2. Amphibolite and hornblendite; 3. Banded hornblende gneiss and amphibolite; 4. Corundum in outcrop; 5. Corundum-bearing boulder; 6. Outcrop; 7. Foliation and lineation; 8. Number of important sample locality.

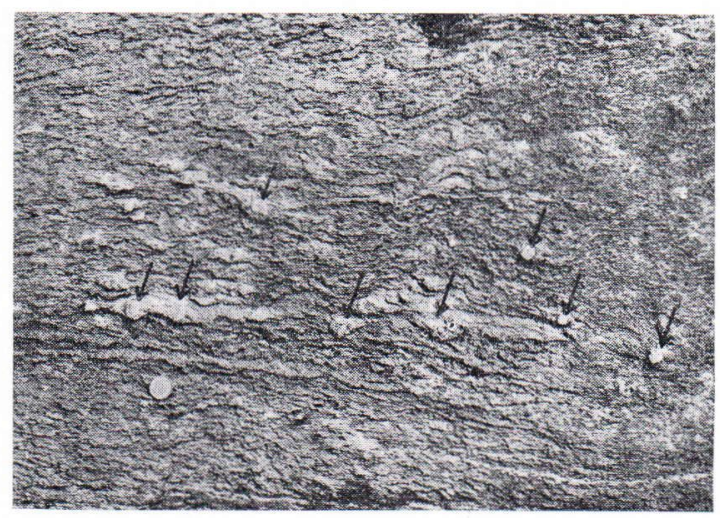

Fig. 3. Corundum-bearing amphibolite, outcrop 41. Corundum is visible as white roundish spots, some of which are marked with a small arrow. $1 / 10$ of natural size. Photo Ilmari Haapala. suggests that the corundum-bearing rock forms a conformable zone in the amphibolite-hornblendite formation. Even in the richest part, the corundum content is only a few per cent. A hand specimen rich in corundum was polished and the corundum content ( 3.5 per cent) was determined with a planimeter.

A corundum-bearing sample (type 2) taken from outcrop 41 was analysed chemically by Pentti Ojanperä. The result was: $\mathrm{SiO}_{2}$ 45.09, $\mathrm{TiO}_{2}$ 0.18, $\mathrm{Al}_{2} \mathrm{O}_{3}$ 19.78, $\mathrm{Cr}_{2} \mathrm{O}_{3} 0.05, \mathrm{Fe}_{2} \mathrm{O}_{3}$ 1.52, $\mathrm{FeO} 3.84, \mathrm{MnO} 0.09, \mathrm{MgO} 14.67, \mathrm{CaO} 10.77$, $\mathrm{Na}_{2} \mathrm{O}$ 1.29, $\mathrm{K}_{2} \mathrm{O} 0.26, \mathrm{P}_{2} \mathrm{O}_{5} 0.01, \mathrm{CO}_{2} 0.00$, $\mathrm{H}_{2} \mathrm{O}+2.24, \mathrm{H}_{2} \mathrm{O}-0.04$, total 99.83. Sp. gr. 3.03. The corresponding Niggli numbers are: si 88.64 , al 22.95, fm 51.58, c 22.68, alk 2.78, mg 0.87, $k 0.12$, ti 0.27 and $p 0.01$.

The titanium content of this rock is much lower, and the alumina content higher, than in normal magmatic basic rocks (see e.g. Turner and Verhoogen, 1960).

On the western side of the amphibolite-hornblendite formation is granite gneiss - a strongly tectonized rock with quartz, microcline, plagioclase, biotite and hornblende as the main minerals.

In the east, the amphibolite-hornblendite formation is in contact with a finer grained banded amphibole gneiss-amphibolite formation. The banded structure is due to the concentration of quartz and plagioclase, and hornblende in different bands. Some quartz in these rocks occur as thin veins and is younger than the other main minerals. Hornblende is much darker than in the amphibolite-hornblendite formation. Plagioclase is commonly strongly altered. In some thin sections almost fresh andesine, and areas in which andesine is replaced by albite and clinozoisite-epidote, can be seen. Titanite, calcite and opaque minerals occur in small amounts.

\section{Corundum}

The corundum crystals found in the outcrops are generally about one centimeter or less in diameter, though crystals as large as $3-4 \mathrm{~cm}$ 


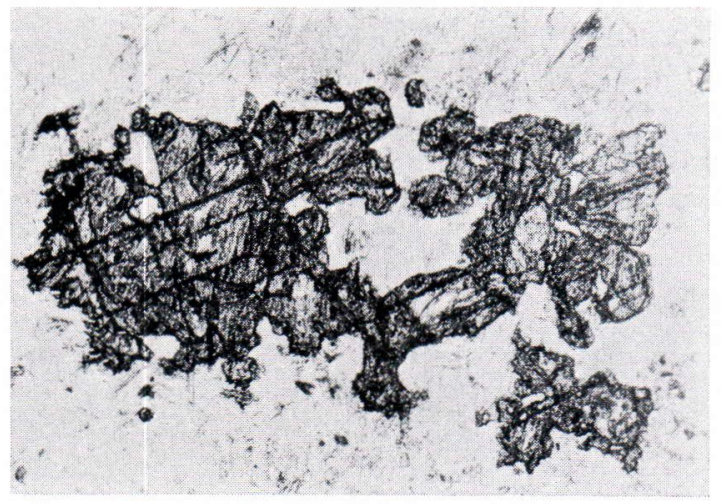

Fig. 4. Remants of corundum in a chlorite matrix. One nicol, magn. 50 x. Photo Erkki Halme.

in diameter can be found. By far the largest and most striking corundum crystal is that of the original boulder sample (Fig. 1). The colour is normally pink, white or red, but under the binocular microscope also some deep blue corundum grains were detected in the material crushed for mineral separation. At the margins, the crystals are usually replaced by colourless optically positive chlorite (Fig. 4), and sometimes also by hornblende or sericite. The replacement is often almost complete so that only scattered remnants with a uniform orientation remain (Fig. 4).

\section{Hornblende}

In general, hornblende represents the most abundant mineral of the amphibolite-hornblendite formation, though in some samples the amount of plagioclase exceeds that of hornblende. The colour of hornblende is green in a hand specimen, but in thin section the mineral is colourless.

Hornblende was separated for chemical analysis from a sapphirine-bearing sample $(40 / \mathrm{IH} / 67)$ taken from outcrop 40. The physical properties of this material are given in Table 1 . The unit cell dimensions were determined by the Buerger precession method using $\mathrm{Zr}$-filtered Mo radiation. The film skrinkage was calibrated by recording silicon [111]-axis zero-level precession photographs on the same films. The specific gravity was determined with Clerici solution and a Westphal balance. Refractive indices were measured in $\mathrm{Na}$ light by the immersion method. A universal stage was used in measuring the optic angle. The same methods were also employed in determining the physical properties of gedrite, sapphirine and kornerupine.

On the basis of the formula calculated from the chemical analysis (Table 1), the mineral is magnesio-hornblende (Leake 1968). In the three-

TABLE 1

Chemical composition and physical properties of hornblende. Chemical analysis by Pentti Ojanperä

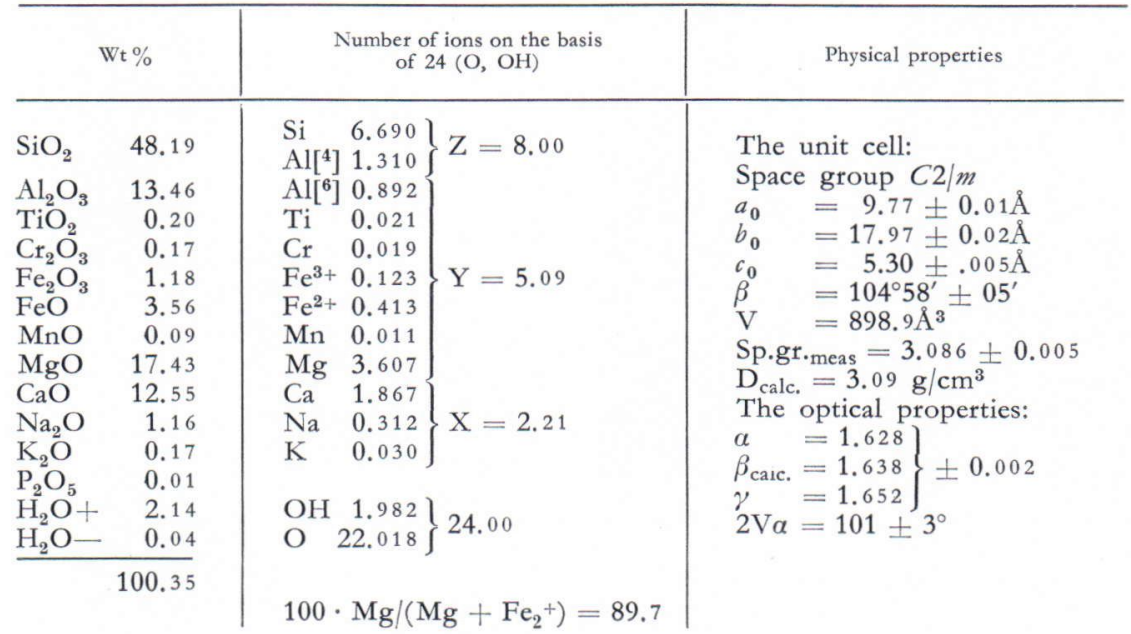


dimensional coordinate system proposed by Whittaker (1968) for the classification of amphiboles the mineral falls into the composition space centered on coordinates 211 . The alumina content is remarkably high, reflecting the high alumina content of the rock as a whole. This mineral is biaxially positive and thus differs from most common hornblendes.

Hornblende from the kornerupine-bearing sample has refractive indices $\alpha 1.630$ and $\gamma 1.654$, suggesting a slightly lower $\mathrm{Mg}: \mathrm{Fe}$ ratio than in the hornblende of the sapphirine-bearing sample.

\section{Gedrite}

Gedrite is found as long prismatic crystals in the sapphirine-bearing rock. The crystals may be several centimeters in length. Macroscopically, the mineral is beige in colour but in thin section it is colourless. It is very difficult to distinquish gedrite from hornblende in thin section, because both minerals appear to be colourless. For the universal stage measurements the gedrite grains had to be identified from a polished thin section by microprobe.

A partial chemical analysis was made from a polished thin section of the sample $40 / \mathrm{IH} / 67$ using the microprobe technique (Table 2). The ratio $\mathrm{Mg} /(\mathrm{Mg}+\mathrm{Fe})$ is 84.7 , i.e. somewhat lower than in hornblende (cf. Klein 1968). The optical properties are in good agreement with the diagrams for the relationships between these variables and the chemical composition of antophyllite-gedrite (Seki and Yamasaki 1957).

\section{Sapphirine}

Deep blue sapphirine is found in one outcrop (40) and in one boulder (7). In both cases, the rock has the mineral assemblage hornblendegedrite-sapphirine-corundum (-chlorite-anorthite). Sapphirine is typically intergrown with hornblende (Fig. 5) or corundum, and is in many cases partially replaced by chlorite. Some larger sapphirine crystals are repeatedly twinned on.

From a crystal splinter of the sapphirine, $c$-axis zero-, first-, second-, and third-level Weissenberg photographs were taken with Ni-filtered $\mathrm{Cu}$ radiation, as well as $b$ - and [101] -axis zero-, first-, and second-level precession photographs with Zr-filtered Mo radiation. The systematic extinctions ( $b k l$ no conditions, $b 0 l$ absent if $b$ is odd, $0 k 0$ absent if $k$ is odd) agree with the requirements of the space group $P 2_{1} / a$, recorded by Moore (1969) for Fiskenaesset sapphirine. The systematic extra-extinctions recorded for sapphirine from four localities by Fleet (1967) do not exactly fit the Kittilä material. After long expo-

TABLE 2

Chemical composition and physical properties of gedrite. Electron microprobe analysis by Jaakko Siivola

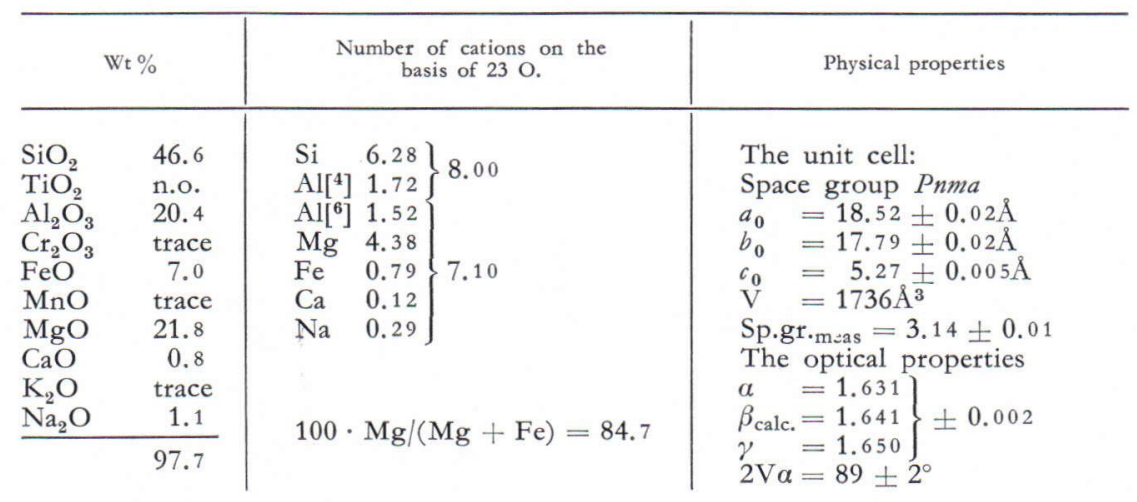




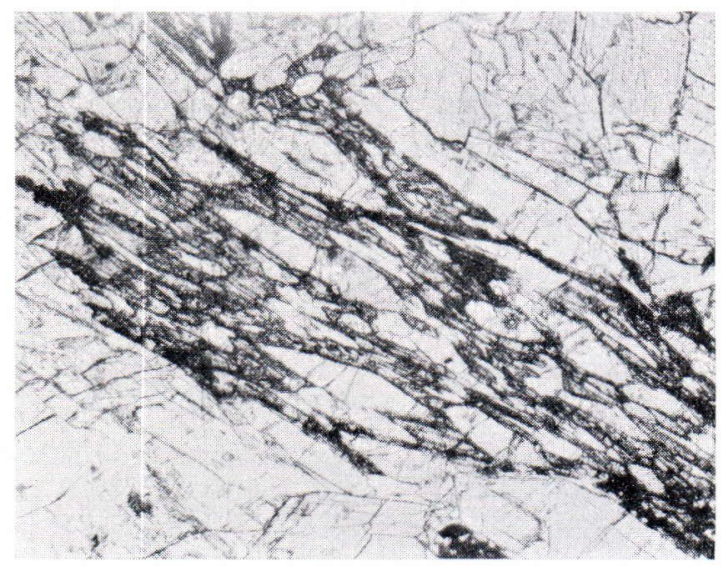

Fig. 5. Needle-like sapphirine grains (dark grey) intergrown with hornblende. Sample from boulder No. 7. One nicol, magn. 50 x. Photo Erkki Halme.

sures some very weak reflections incompatible with Fleet's rules were visible on the films. When comparing the extinction rules, the different choices of axes in Fleet (1967) and in the present study were taken into account. Thus, for example, the following »forbidden» reflections were noticed: $\overline{6} 02$ (402), $\overline{12.312 ~(0312), ~} \overline{12} .712$ (0712), $\overline{3} 12$ (112), and $\overline{3} 32$ (132). The indices in brackets refer to the Fleet cell.
Sapphirine was analysed from a polished thin section of sample $40 / \mathrm{IH} / 67$ by microprobe (Table 3). The silica content is a little lower and the alumina content somewhat higher than in the previous sapphirine analyses (Deer, Howie and Zussman 1963, Wilson and Hudson 1967, Lutts and Kopaneva 1968, Forestier and Lasnier 1969) suggesting a pronounced coupled substitution $\mathrm{Al}, \mathrm{Al}$ for $\mathrm{Mg}$, Si. The asymmetric formula unit contains $\mathrm{Mg}_{3 \cdot{ }_{38}} \mathrm{Fe}^{2+}{ }_{0 \cdot 15} \mathrm{Fe}^{3+}{ }_{0 \cdot 20}$ $\mathrm{Al}_{8 \cdot 84} \mathrm{Si}_{1 \cdot 45} \mathrm{O}_{20}$.

\section{Kornerupine}

Kornerupine was recognised only in the original boulder sample found by Mikko Tervo (Fig. 1). The main minerals in this sample are hornblende, corundum, kornerupine, sericite, clinozoisite and chlorite. Fresh plagioclase (anorthite), tourmaline (dravite) and chromite occur in smaller amounts. Kornerupine occurs as pale bluish green crystals up to $1 \mathrm{~cm}$ in diameter. In thin section, the mineral is colourless and has indistinct $\{110\}$ cleavage. The kornerupine crystals are veined and strongly replaced by chlorite and fine-grained mica (Fig. 6), and the associated plagioclase grains are in general

TABLE 3

Chemical composition and physical properties of sapphirine. Electron microprobe analysis by Jaakko Siivola

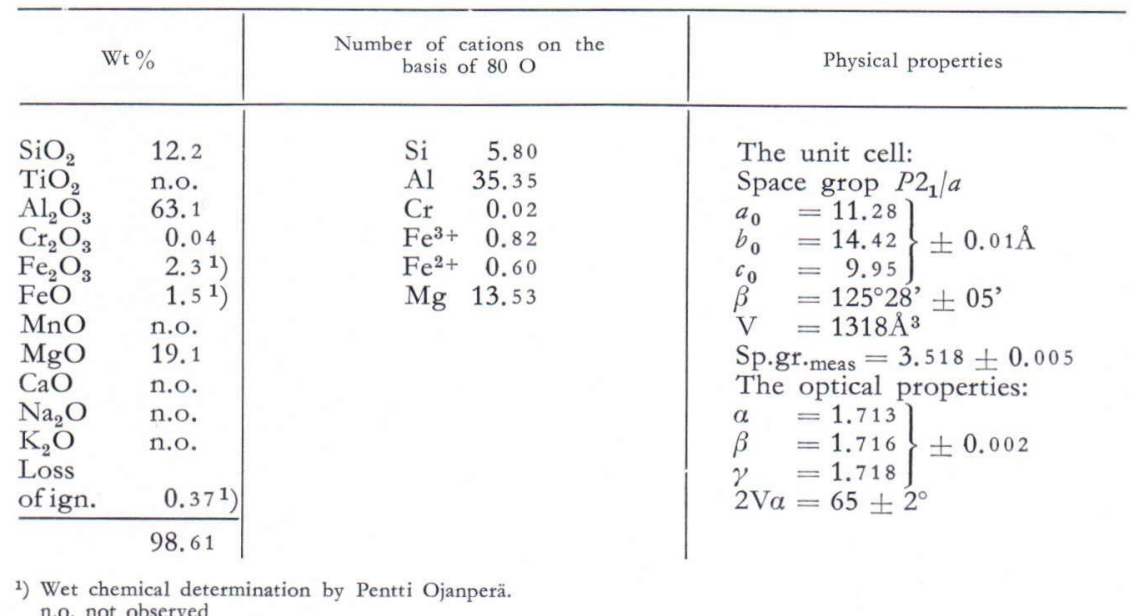


completely saussurized. Idiomorphic twinned clinozoisite crystals are present and may be up to two millimeters long (Fig. 7). Remnants of strongly altered idiomorphic plagioclase crystals are common inclusions in kornerupine (Fig. 8). Unaltered plagioclase can be found only as enclosed, shielded crystals. A microprobe analysis of such a crystal showed it to be anorthite. Corundum may also occur as inclusions in kornerupine.

A series of precession photographs about all the crystallographic axes were taken to determine the space group and unit cell dimensions of kornerupine. The conditions for non-extinction of the reflections were: $b k l b+k=2 \mathrm{n}, \quad b 0 l$ $l=2 n$. These data are compatible with space groups $C m c m, C m c 2_{1}$ and $C 2 \mathrm{~cm}$, conforming to the studies of Bartl (1965), McKie (1965) and Knorring et al. (1969). Moore and Bennet (1968) recorded space group $\mathrm{Cmcm}$ on the basis of a crystal structure analysis of the Mautia Hill kornerupine.

The Kittilä kornerupine was so strongly metasomatized that it was not possible to obtain sufficient pure material for a complete wet chemical analysis. Therefore, the main part of the analysis was made by microprobe. $\mathrm{H}_{2} \mathrm{O}+$ was determined using a Penfield tube from a small amount $(60 \mathrm{mg})$ of carefully hand-picked material. Iron was detemined by a wet chemical method and boron spectrochemically from material containing small amounts of alteration products as impurities. The amount of impurities was so small that their influence on the iron and boron contents is believed to be insignificant. However, the water content may be slightly high. According to the microprobe analysis, the total iron content calculated as $\mathrm{FeO}$ is $4.9 \%$.

The boron content (Table 4) is somewhat lower than in other contemporary kornerupine analysis (cf. Knorring et al. 1969). Correspondigly, the silica content is sightly greater than usually, suggesting an unusually low substitution of B for Si. Moore and Bennett (1968) suggested the simplified formula $\mathrm{Mg}_{3} \mathrm{Al}_{6}(\mathrm{Si}, \mathrm{Al})_{5} \mathrm{O}_{21}(\mathrm{OH})$

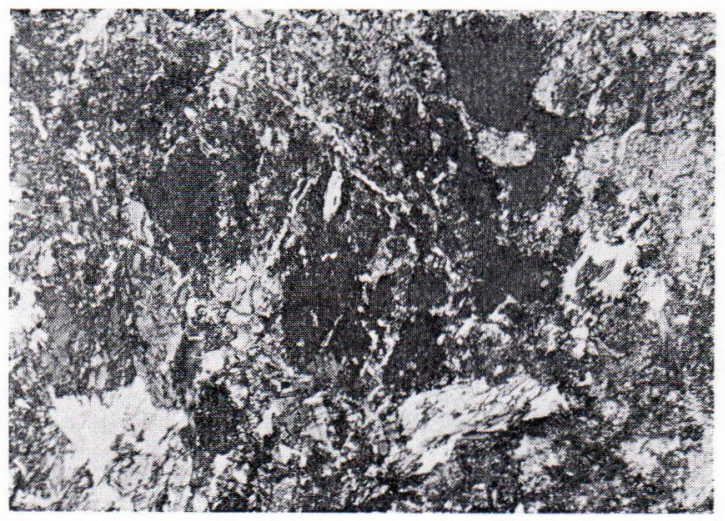

Fig. 6. Remnants of kornerupine in a chlorite-sericite matrix. Crossed nicols. magn. 50 x. Photo Erkki Halme.

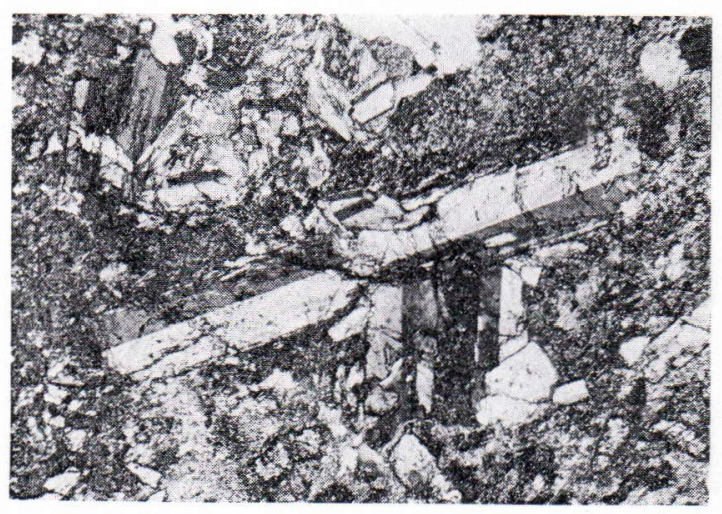

Fig. 7. Clinozoisite crystals in a chlorite-sericite matrix. Crossed nicols, magn. $50 \mathrm{x}$. Photo Erkki Halme.

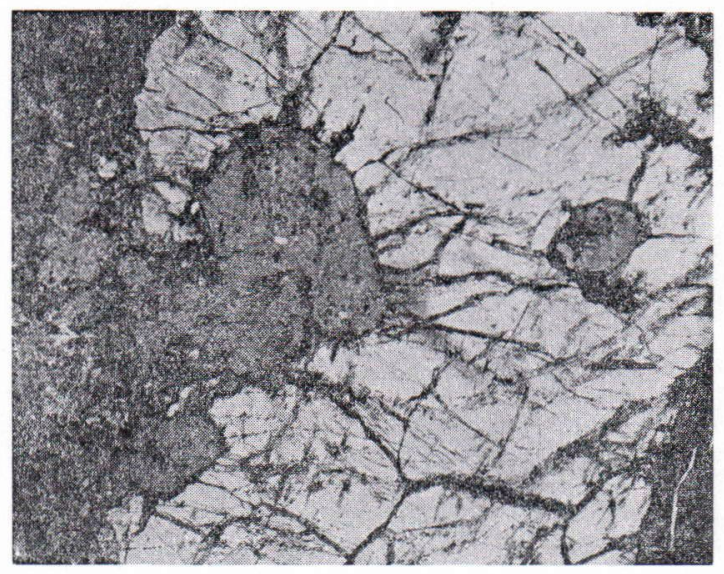

Fig. 8. Plagioclase crystals in kornerupine. Completely altered crystals on the border of the kornerupine grain on the left, shielded fresh anorthite crystal on the right. Crossed nicols, magn. 50 x. Photo Erkki Halme. 
TABle 4

Chemical composition and physical properties of kornerupine. Electron probe microanalysis by Jaakko Siivola

\begin{tabular}{|c|c|c|c|}
\hline \multicolumn{2}{|c|}{ Wt \% } & $\begin{array}{l}\text { Number of ions on the basis } \\
\text { of } 88(\mathrm{O} . \mathrm{OH})\end{array}$ & Physical properties \\
\hline $\begin{array}{l}\mathrm{SiO}_{2} \\
\mathrm{~B}_{2} \mathrm{O}_{3} \\
\mathrm{TiO}_{2} \\
\mathrm{Al}_{2} \mathrm{O}_{3} \\
\mathrm{Cr}_{2} \mathrm{O}_{3} \\
\mathrm{Fe}_{2} \mathrm{O}_{3} \\
\mathrm{FeO} \\
\mathrm{MnO} \\
\mathrm{MgO} \\
\mathrm{CaO} \\
\mathrm{Na} \\
\mathrm{K}_{2} \mathrm{O} \\
\mathrm{H}_{2} \mathrm{O} \\
\end{array}$ & $\begin{array}{l}31.7 \\
1.0^{1} \text { ) } \\
\text { n.o. } \\
43 . .^{5} \\
0.33 \\
2.3^{2} \text { ) } \\
1.9^{2} \text { ) } \\
0 . .^{2} \\
17.4 \\
0.07 \\
\text { trace } \\
\text { n.o. } \\
\left.1.5^{2}\right) \\
\end{array}$ & $\begin{array}{lr}\mathrm{Si} & 15.62 \\
\mathrm{~B} & 0.85 \\
\mathrm{Al} & 25.27 \\
\mathrm{Cr} & 0.13 \\
\mathrm{Fe}^{3+} & 0.85 \\
\mathrm{Fe}^{2+} & 0.78 \\
\mathrm{Mn} & 0.04 \\
\mathrm{Mg} & 12.78 \\
\mathrm{Ca} & 0.04 \\
\mathrm{OH} & 4.93 \\
\mathrm{O} & 83.07\end{array}$ & 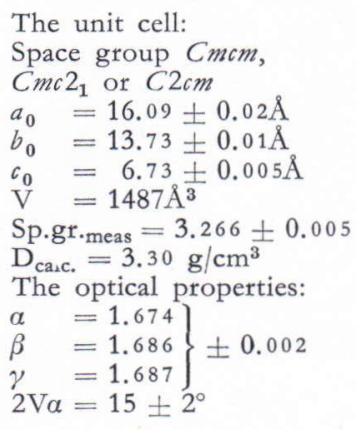 \\
\hline
\end{tabular}

for kornerupine. The formula calculated for the Kittilä kornerupine is $\mathrm{Mg}_{3 \cdot 2} \mathrm{Fe}^{+2}{ }_{0 \cdot 2} \mathrm{Al}_{6 \cdot 3} \mathrm{Fe}^{3+}{ }_{0 \cdot 2}$ $\mathrm{Si}_{3 \cdot 9} \mathrm{~B}_{0 \cdot 2} \mathrm{O}_{20 \cdot 8}(\mathrm{OH})_{1 \cdot 2}$.

A partial semiquantitative microprobe analysis of the colourless, optically positive chlorite associated with kornerupine gave $\mathrm{SiO}_{2} 29.3$, $\mathrm{Al}_{2} \mathrm{O}_{3}$ 26.6, $\mathrm{FeO} 6.8$ and $\mathrm{MgO} 21.9$ wt \%. This indicates that the mineral is clinochlore. An analysis of tourmaline by a similar method gave $\mathrm{SiO}_{2}$ 35.6, $\mathrm{Al}_{2} \mathrm{O}_{3}$ 35.6, $\mathrm{FeO} 2.0, \mathrm{MgO} 10.8$, $\mathrm{CaO} 1.5-1.8$, and $\mathrm{Cr}_{2} \mathrm{O}_{3} 0.41$ wt \% showing the mineral to be dravite. Tourmaline often occurs at the margins of the corundum crystals and may penetrate them as thin veinlets. This suggests boron metasomatism.

\section{Discussion}

The literature dealing with the rare rockforming mineral sapphirine is fairly comprehensive. Types of sapphirine and kornerupine occurrences and their stability relations are summarized by Vogt (1947), Sørensen (1955), Deer, Howie and Zussman (1963), Herd et al. (1969), Forestier and Lasnier (1969) and Schreyer and Seifert (1969). The most common type is composed of sapphirine-bearing metamorphosed basic-ultrabasic rocks of granulite terrains. The minerals commonly associated with sapphirine are orthopyroxene, hornblende, gedrite, phlogopite, plagioclase, cordierite, spinel, corundum and rarely kornerupine. Recently, sapphirine has also been described from rocks of the skarn type (Knorring 1967, Rouhunkoski 1968, p. 29).

In his study on the sapphirine occurrences, Sørensen (1955) discussed the stability relations of sapphirine. He concluded that sapphirine was formed in rocks rich in alumina and magnesia but poor in silica, which have been metamorphosed under the P-T conditions corresponding to high amphibolite facies or low granulite facies. His study largely conforms to the conclusions of Vogt (1947) and Ramberg (1948). According to Turner and Verhoogen, (1960) sapphirine is formed under conditions of hornblende-granulite subfacies. Herd et al. (1969) made a detailed study of the petrology of different sapphirine-bearing rocks of the Fiskenaesset region in West Greenland. These rocks were derived from layered spinel-bearing ultramafic rocks which formed a minor part of chromitebearing layered anorthosite complex. The comp- 
lex has undergone hornblende-granulite facies metamorphism followed by cordierite-amphibolite facies metamorphism. Herd et al. distinguished enstatite, pargasite, gedrite and phlogopite types of sapphirine-bearing assemblages, which represent increasing degrees of $\mathrm{Si}, \mathrm{Ca}, \mathrm{K}$ and $\mathrm{H}_{2} \mathrm{O}$ metasomatism related to shearing and deformation. Herd et al. conclude (op. cit, p. 41): "Sapphirine was thus formed under hornblendegranulite facies conditions, was stable in reduced amounts under cordierite-amphibolite facies conditions and was stable even in relatively calcium rich assemblages where it was able to crystallise under amphibolite facies conditions». Accordingly they state that sapphirine is stable under a wide range of P-T conditions, but within a limited range of chemical environments.

According to the experimental studies of Schreyer and Seifert (1969) of the system $\mathrm{MgO}-\mathrm{Al}_{2} \mathrm{O}_{3}-\mathrm{SiO}_{2}-\mathrm{H}_{2} \mathrm{O}$ assemblages containing sapphirine, gedrite and kornerupine may be formed at elevated pressures and intermediate temperatures. Sapphirine, corundum and gedrite appear as stable coexisting phases in the system $\mathrm{MgO}-\mathrm{Al}_{2} \mathrm{O}_{3}-\mathrm{SiO}_{2}-\mathrm{H}_{2} \mathrm{O}$ at a pressure of $14 \mathrm{~kb}$ and temperature $850^{\circ}$ (Schreyer 1968, Fig. 27). At higher temperatures $\left(810^{\circ}-910^{\circ} \mathrm{C}\right.$, depending on the pressure) gedrite breaks down to enstatitebearing assemblages. Boronfree kornerupine appears to be stable at $8-13 \mathrm{~kb}$ and $850^{\circ} \pm 50^{\circ} \mathrm{C}$. Because of the greater complexity of natural systems, however, the phase relations in the system $\mathrm{MgO}-\mathrm{Al}_{2} \mathrm{O}_{3}-\mathrm{SiO}_{2}-\mathrm{H}_{2} \mathrm{O}$ can be applied only with reservations. For example, the Kittilä material contains notable amounts of calcium, iron and alkalies, which would change the PTconditions.

The corundum-sapphirine-kornerupine occurrence described in this paper is located just outside the great granulite complex of Lapland (Mikkola 1937, Mikkola and Sahama 1936). Poor exposures make it difficult to draw any detailed conclusions concerning the genesis and petrology of the amphibolite-hornblendite formation. In every case it is apparent that the complex was metamorphosed under at least two different P-T conditions; (a) under high-grade amphibolite low-grade granulite facies, and (b) with slight retrogression under greenschist facies. According to Winkler (1967) gedrite is not stable under granulite facies conditions. The sapphirinebearing assemblage (type 3, p. 222) corresponds to a transition between the pargasite and gedrite types of Herd at al. (1969).

Zakrutkin (1968) has shown that the composition of hornblende depends on the metamorphic facies. Plotted on his diagram based on $\mathrm{Al}^{[4]}$ and $\mathrm{Al}^{[6]}$ contents, the analysed hornblende from the sapphirine-bearing assemblage falls into the amphibolite facies field but very near the junction of the albite-apidote-amphibolite facies. A similar result is obtained from Zakrutkin's diagram based on the contents of $\left(\mathrm{Fe}^{3^{+}}+\mathrm{A}^{[6]}+\right.$ Ti) and $\left(\mathrm{Mg}+\mathrm{Fe}^{2^{+}}+\mathrm{Mn}\right)$. The high content of $\mathrm{Al}^{[6]}$ suggests unusually high pressure during metamorphism (Kostyuk and Sobolev 1969).

It is not clear what the rocks were before the high-grade metamorphism. The Niggli numbers (p. 223) suggest the formation to be an »ortho-amphibolite». Compared with $c$ and al-alk the $m g$ number is somewhat higher than it should be in mixtures of normal pelites or semipelites and dolomites or limestones ( $c f$. Leake 1964). Also the occurrence of chromite as an accessory mineral points to igneous origin. The large hornblende phenocrysts are possibly pseudomorphs after pyroxene. The high alumina and magnesia contents may be derived from the primary spinel-rich layers in the mafic-ultramafic formation, as is the case in the Fiskenaesset region (Herd et al. 1969). Spinel has been described from some ultramafic rocks near to the granulite complex of Lapland (Mikkola and Sahama 1936). However, the data are insufficient for excluding the possibility of metasedimentary origin.

It appears that the main metamorphism took place under high pressure and high temperature conditions at or near the boundary between amphibolite and granulite facies. Greenschist 
facies metamorphism has slightly retrogressed the mineral assemblages. Anorthite has altered in varying amounts to sericite and clinozoisite. Corundum, hornblende, sapphirine and kornerupine are partly replaced by chlorite. The retrograde metamorphism (and metasomatism) appears to have been most intense in the rocks represented by the kornerupine-bearing sample.
In this sample unshielded plagioclase is completely replaced by sericite and clinozoisite, and kornerupine very strongly by chlorite. Thus, the retrograde metamorphism shows a tendency to destroy corundum, sapphirine and kornerupine.

Acknowledgements - The authors are indebted to $\mathrm{Mr}$. Erkki Halme for taking the photographs.

\section{REFERENCES}

BArtL, H. (1965) Zur Kornerupinstruktur. Neues Jahrb. f. Mineral., Monatshefte, 151-153.

FLEeT, S. G. (1967) Non-space group absences in sapphirine. Mineral. Mag. 36, 449-450.

Forestier, F. H. and Lasnier, B. (1969) Découverte de niveaux d'amphibolites á pargasite, anorthite, corindon et saphirine dans les la vallée du Haut-Allier. Contr. Mineral. and Petrol. 23, 194-235.

Deer, W. A., Howie, R. A., and Zussman, J. (1962) Rock-forming minerals, vol. 1, ortho- and ring silicates. Longmans, London.

- (1963) Rock-forming minerals, vol. 2, chain silicates. Longmans, London.

Herd, R. K., Windley, B. F. and Ghisler, M. (1969) The mode of occurrence and petrogenesis of the sapphirine-bearing and associated rocks of West Greenland. Rapp. Grønlands geol. Unders., No. 24.

KleIN, C., JR (1968) Coexisting amphiboles. Journ. Petrol. 9, 281-330.

v. Knorring, O. (1967) A skarn occurrence of sinhalite from Tanzania. Res. Inst. African Geol. and Dept. Earth Sci., Univ. of Leeds, 11th. Ann. Rept. (196566), 40.

v. Knorring, O., Sahama, Th. G. and Lehtinen, M. (1969) Kornerupine-bearing gneiss from Inanakafy near Betroka, Madagascar. Bull. Geol. Soc. Finland 41, $79-84$.

Kostyuk, E. A. and Soвolev, V. S. (1969) Paragenetic types of calciferous amphiboles of metamorphic rocks. Lithos 2, 67-81.

LEAKE, B. E. (1964) The chemical distinction between ortho- and para-amphibolites. Journ. Petrol. 5, $238-254$.

- (1968) A catalog of analysed calciferous and subcalciferous amphiboles together with their nomenclature and associated minerals. Geol. Soc. Amer. Spec. Paper 98.

Lutrs, B. G. and Kopaneva, L. N. (1968) A pyropesapphirine rock from the Anabar massif and its conditions of metamorphism. Dokl. Acad. Sci. U.S.S.R., Earth Sci. Sect., 179, 161-163. Transl. from Dokl. Akad. Nauk. SSSR, 179, 1200-1202.
MскіE, D. (1963) Order-disorder in sapphirine. Mineral. Mag. 33, 635-645.

- (1965) Magnesium aluminium borosilicates: Kornerupine and grandidierite. Mineral. Mag. 34, 346-357.

Miknola, E. (1937) Pre-Quaternary rocks. Sodankylä (Sheet C 7). General geological map of Finland, 1: 400000 .

Mikkola, E. and Sahama, Th. G. (1936) The region to the South-West of "Granulite series» in Lapland and its ultrabasics. C.R.Soc. géol. Finlande 9, Bull. Comm. géol. Finlande 115, 357-371.

Moore, P. B. (1969) The crystal structure of sapphirine. Amer. Mineral. 54, 31-49.

Moore, P. B. and Bennetr, J. M. (1968) Kornerupine: its crystal structure. Science $159,524-526$.

RAMBerG, H. (1948) On sapphirine-bearing rocks in the vicinity of Sukkertoppen (West Greenland). Meddr Grønland, Bd. 142, Nr. 5.

Roununkoski, P. (1968) On the geology and geochemistry of the Vihanti zink ore deposit, Finland. Bull. Comm. géol. Finlande 236.

SCHREYeR, W. (1968) A reconnaissance study of the system $\mathrm{MgO}-\mathrm{Al}_{2} \mathrm{O}_{3}-\mathrm{SiO}_{2}-\mathrm{H}_{2} \mathrm{O}$ at pressures between 10 and $25 \mathrm{~kb}$. Carnegie Inst. Washington Year Book $66,380-392$.

Schreyer, W. and Seifert, F. (1969) High-pressure phases in the system $\mathrm{MgO}-\mathrm{Al}_{2} \mathrm{O}_{3}-\mathrm{SiO}_{2}-\mathrm{H}_{2} \mathrm{O}$. Amer. Journ. Sci., Schairer vol. 267-A, 407-443.

Sekr, Y. and Yamasaki, M. (1957) Aluminian ferroantophyllite from Kitamaki mountainland, north-eastern Japan. Amer. Mineral. 42, 506-520.

Sørensen, H. (1955) On sapphirine from West-Greenland. Bull. Grønlands geol. Unders. 12.

Turner, F. J. and Verhoogen, J. (1960) Igneous and metamorphic petrology. Second edition. McGrawHill, New York.

Vogr, Tн. (1947) Mineral assemblages with sapphirine and kornerupine. Bull. Comm. géol. Finlande 140, $15-24$.

Whittaker, E. J. W. (1968) Classification of amphiboles. Min. Soc., I.M.A. vol. (I.M.A., Papers and Proc. 5th Gen. Meeting, Cambridge 1966), 231-242. 
Wilson, A. F. and Hudson, D. R. (1967) The discovery of beryllium-bearing sapphirine in the granulites of the Musgrave Ranges (Cntral Australia) Chem. Geol. 2, $209-215$.

WINKLER, H. G. F. (1967) Die Genese der metamorphen Gesteine. Springer-Verlag. Berlin.
ZAKRUTKIN, V. V. (1968) On the evolution of amphiboles accompanied by metamorphism. Zap. Vses. Mineral. Obsch. 97, 13-23. (In russian).

Manuscript received, February 5, 1971. 